\title{
Melanoides tuberculatus (GASTROPODA: THIARIDAE) AS INTERMEDIATE HOST OF HETEROPHYIDAE (TREMATODA: DIGENEA) IN RIO DE JANEIRO METROPOLITAN AREA, BRAZIL
}

\author{
Tami BOGÉA(1), Fernanda Martins CORDEIRO(2) \& Janaína Silva de GOUVEIA(2)
}

\begin{abstract}
SUMMARY
In the late 1960s, Melanoides tuberculatus snails were introduced in Brazil from North/East Africa and Southeast Asia. The first records of specimens infected with cercariae were registered in Rio de Janeiro State in 2001. The present study reports the occurrence of M. tuberculatus infected with larval trematodes in Rio de Janeiro City. Bottom sediment was collected with dip nets and sieved through 0.25 inch-mesh screening. Snails were transported to the laboratory in vials with stream water, then measured and individually isolated in glass vials with distilled water. They were exposed to artificial light and temperature to induce cercarial emergence. The most actively emerging cercariae were processed by differential staining and silver nitrate impregnation methods. Negative snails were subsequently dissected. Approximately 700 snails were collected. Snail total lengths ranged from 1.2 to $3.3 \mathrm{~cm}$. The prevalence rate was $15.76 \%$ although $53.76 \%$ of the snails were found infected in one of the sites. Infected snails were infected with rediae and pleurolophocercous cercariae. Cercarial morphology and chaetotaxy were consistent with those of the family Heterophyidae mostly due to the presence of median dorsal and ventral fins on the tail and the absence of CI dorsal sensory receptors.
\end{abstract}

KEYWORDS: Melanoides tuberculatus; Cercaria; Heterophyidae; Rio de Janeiro City; Parasitism; Biodiversity.

\section{INTRODUCTION}

Snails of the species Melanoides tuberculatus (Müller, 1774) (Gastropoda: Thiaridae) have been monitored worldwide because they may serve as intermediate hosts of parasitic trematodes. They originate from North/East Africa and Southeast Asia, where they participate in paragonimiasis and chonorchiasis transmission cycles ${ }^{11}$.

M. tuberculatus was introduced in Brazil around $1967^{18}$, when four specimens were collected in Santos, São Paulo State. Since then, its distribution has been expanding ${ }^{7,19}$. In 2001, THIENGO et al. ${ }^{16}$ reported the occurrence of this species infected with pleurolophocercous cercariae in two municipalities of Rio de Janeiro State.

In the present study, we report the occurrence of $M$. tuberculatus infected with larval trematodes in the metropolitan area of Rio de Janeiro, Brazil. Cercarial morphology and chaetotaxy are also described in detail.

\section{MATERIAL AND METHODS}

Collection and identification of infected snails: Approximately 700 snails of $M$. tuberculatus, with shell lengths varying from 1.2 to 3.3 $\mathrm{cm}$, were collected from June 2003 through October 2004. The collecting sites were as follows: (1) drainage system of a vegetable garden in a local farm in Vargem Pequena (Granja site), (2) public sewage system of Vargem Pequena (Boca do Mato site), (3) artificial ponds of a social club in Vargem Grande (Pacuí site), (4) streams near a rain forest State park in Vargem Grande (PEPB site), (5) drainage system of a condo in Vargem Pequena (Condo site), and (6) streams of a rain forest City park in Prainha (PNMP site).

Bottom sediment was collected with dip nets and was sieved through 0.25 -inch-mesh screening. The snails were transported to the laboratory in vials containing stream water. In the laboratory, they were measured and individually isolated in glass vials with $5 \mathrm{~mL}$ of distilled water. They were then exposed to artificial light $(60 \mathrm{w})$ and temperature (approximately $30{ }^{\circ} \mathrm{C}$ ) for two hours a day every two days for up to two weeks to induce cercarial emergence. The most actively emerging cercariae were collected with fine glass pipettes and processed accordingly. Forty days after the collection, the negative snails were dissected for detection of larval stages of digeneans.

Specimen preparation and study: Twenty cercariae were processed as whole mounts ${ }^{4}$. They were fixed in hot $5 \%$ formalin, stained with Semichon's acetocarmine, dehydrated in graded ethanol series, cleared in methyl salicylate, and mounted in Entelan (Merck, Darmstadt, Germany). Specimens were then measured. For each measurement, the range is given followed in parentheses by mean, standard deviation, and number of specimens measured. All measurements are in

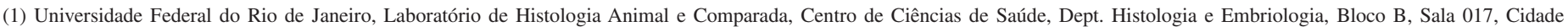
Universitária, 21970-000 Rio de Janeiro, RJ, Brazil.

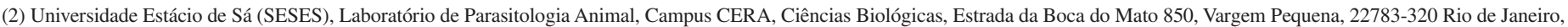
RJ, Brazil.

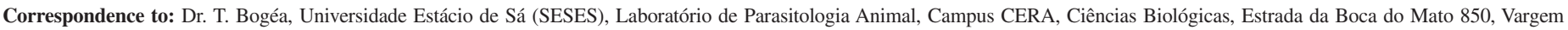
Pequena, 22783-320 Rio de Janeiro, RJ, Brazil. 


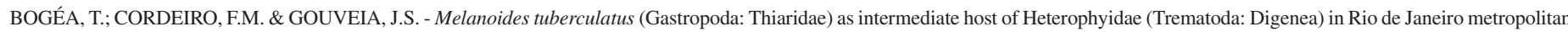
area, Brazil. Rev. Inst. Med. trop. S. Paulo, 47(2):87-90, 2005.

micrometers. Taxonomic identifications followed descriptions by $\mathrm{CABLE}^{4}, \mathrm{SCHELL}^{12}$, and TRAVASSOS et al. ${ }^{17}$. Voucher specimens have been deposited in the Instituto Oswaldo Cruz Helminthological Collection, Brazil.

The standard procedure for silver nitrate impregnation as described by COMBES et al. ${ }^{6}$ allowed the mapping of sensory receptors on the cercarial tegument. Seventy-seven cercariae were fixed in cold $3 \%$ silver nitrate solution, exposed to indirect sunlight for up to two min, rinsed in cold distilled water, and mounted in Aquatex (Merck, Darmstadt, Germany). Illustrations recording the distribution of sensory receptors on the cercarial tegument of each specimen were made. The chaetotaxic pattern was subsequently determined using procedures described elsewhere. ${ }^{2,3}$

\section{RESULTS}

One hundred and thirteen snails were found infected with rediae and cercariae of a single type. Although the estimated prevalence rate for the area was $15.76 \%$, the number of infected snails varied significantly among the six sites (Table 1).

Table 1

Infection of Melanoides tuberculatus in six sites in Rio de Janeiro City, Brazil

\begin{tabular}{lccc}
\hline SITE & $\mathrm{N}$ & $\mathrm{n}$ & $\%$ \\
\hline Granja & 116 & 23 & 19.83 \\
Boca do Mato & 185 & 16 & 8.65 \\
Pacuí & 93 & 50 & 53.76 \\
PEPB & 113 & 0 & 0.00 \\
Condo & 41 & 20 & 48.78 \\
PNMP & 169 & 4 & 2.40 \\
TOTAL & 717 & 113 & 15.76
\end{tabular}

$\overline{\mathrm{N}}=$ number of collected snails; $\mathrm{n}=$ number of infected snails; $\%=$ estimated prevalence rates.

Fifteen out of 20 cercariae were investigated with differential staining. The general cercarial morphology (Fig. 1) is described as follows: body elongate-oval, $142.5-199.5$ (172.4 \pm 19.5 ; 14) long by 22.5 - $135.0(99.4 \pm 31.0 ; 14)$ wide, covered with minute conical spines. Slender tail, usually sigmoid, attached posteroventrally $160.5-255.0$ $(206.4 \pm 27.5 ; 14)$ long by $22.5-75.0(34.6 \pm 12.3 ; 14)$ wide, with median dorsal and ventral fins, a terminal spine, and conspicuous annulations on the tegument. Protrusible subterminal oral sucker 33.0 - $52.5(43.7 \pm 6.4 ; 13)$ long by $30.0-45.0(38.1 \pm 5.1 ; 13)$ wide, with eight enlarged acicular spines $3.0-7.5(6.2 \pm 1.5 ; 12)$ long. Pair of eyespots $7.5-15.0(11.6 \pm 2.5 ; 11)$ long by $6.0-13.5(8.0 \pm 2.18 ; 11)$ wide. Prepharynx present. Globular pharynx $15.0-27.0(16.7 \pm 3.9$; 10) in diameter; oesophagus well developed 3.0 - $22.5(10.5 \pm 8.1 ; 5)$ long by $10.5-13.5(13.8 \pm 2.0 ; 5)$ wide. Intestinal ceca extending posteriorly to excretory vesicle level. Ventral sucker not conspicuous. Seven pairs of penetration glands anterolateral to ventral sucker, with ducts openings concealed in a tegumental fold when oral sucker is retrated, and exposed when it is protruded. Large saccate excretory vesicle. A brownish pigment dispersed throughout the cercarial body except in oral sucker.

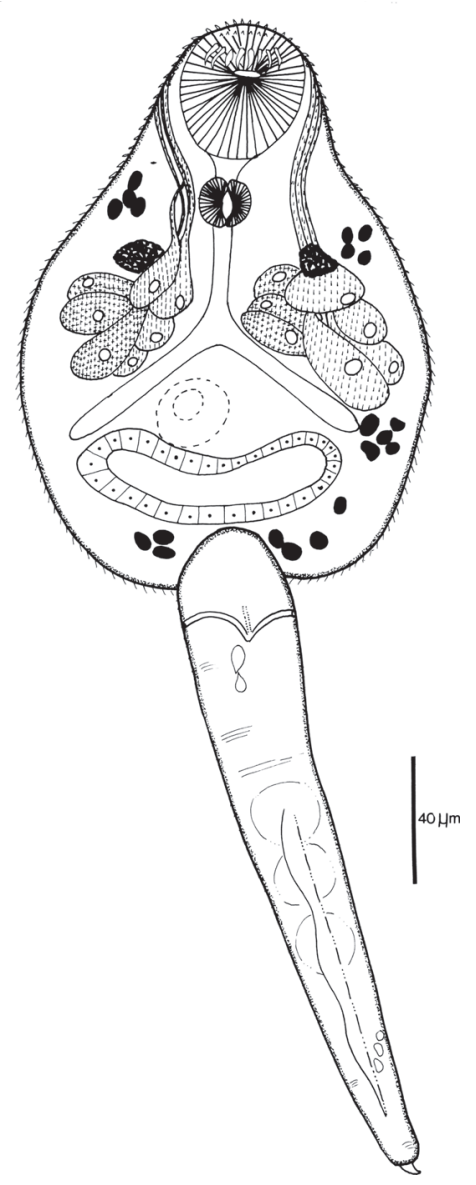

Fig. 1 - General morphology of pleurolophocercous cercaria infecting Melanoides tuberculatus snails as seen with differential staining. Body, ventral view.

A total of 64 out of 77 cercariae were investigated with silver nitrate impregnation. The cephalic, anterior, ventral sucker, posterior, and caudal nerve regions were schematically subdivided into 44 sites. Approximately 87 sensory receptors were found on the cercarial tegument. The chaetotaxic pattern (Fig. 2) is summarized as follows, showing receptors numbers on each side of the cercaria:

Cephalic region: $\mathrm{CI}=1 \mathrm{CI}_{2}, 1 \mathrm{CI}_{4}$; $\mathrm{CII}=2 \mathrm{CII}_{2}, 2 \mathrm{CII}_{4}, 2 \mathrm{CII}_{5}, 3 \mathrm{H}_{2}, 3$ $\mathrm{HL}_{2} ; \mathrm{CIII}=1 \mathrm{CIII}_{2}, 3 \mathrm{CIII}_{4}, 5 \mathrm{CIII}_{5}, 3 \mathrm{H}_{3}, 3 \mathrm{HL}_{3} ; \mathrm{CIV}=2 \mathrm{CIV}_{2}, 2 \mathrm{CIV}_{4}$, $5 \mathrm{CIV}_{5}, 1 \mathrm{H}_{4}, 2 \mathrm{HL}_{4}$; $\mathrm{CV}=2 \mathrm{CV}_{2}, 2 \mathrm{CV}_{4}, 3 \mathrm{CV}_{5}, 1 \mathrm{H}_{5}, 1 \mathrm{HL}_{5}$;

Anterior region: $\mathrm{AI}=2 \mathrm{AI} \mathrm{V}, 4 \mathrm{AI} \mathrm{L}, 3 \mathrm{AI} \mathrm{D}$; $\mathrm{AII}=2 \mathrm{AII} \mathrm{V}, 3 \mathrm{AII} \mathrm{L}, 3$ AII D; AIII = 2 AIII V, 2 AIII L, 1 AIII D;

Posterior region: PI = 1 PI L, 1 PI D; PII = 1 PII L, 2 PII D; PIII = 1 PIII L, 1 PIII D;

Ventral sucker region: $\mathrm{M}=3 \mathrm{M} \mathrm{V}, 1 \mathrm{M} \mathrm{L}, 2 \mathrm{M} \mathrm{D}$;

Tail: $\mathrm{U}=2 \mathrm{UD}$

\section{DISCUSSION}

This study reports that $M$. tuberculatus snails are been infected by larval trematodes in Rio de Janeiro City. The presence of median dorsal and ventral fins is characteristic of pleurolophocercous cercariae. This 

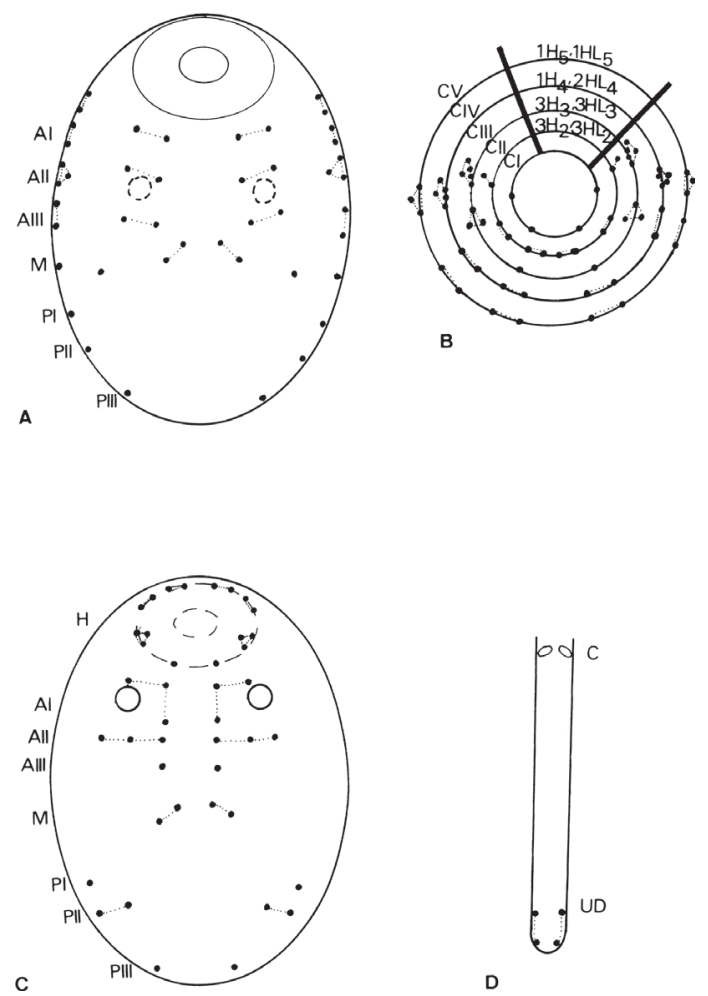

D

Fig. 2 - Chaetotaxy of pleurolophocercous cercaria infecting Melanoides tuberculatus snails as seen with silver nitrate impregnation. A: Body, ventral view. B: Cephalic region, ventral view. C: Body, dorsal view. D: Tail, dorsal view. AI, AII, AIII = anterior sensory receptors; CI, CII, CIII, CIV = cephalic sensory receptors; $\mathrm{CP}=$ caudal pores; H2, H3, H4, H5 = head sensory receptors; HL2, HL3, HL4, HL5 = lateral head sensory receptors; M = midbody sensory receptors; PI, PII, PIII = posterior sensory receptors; UD = caudal sensory receptors.

type has been described in families Acanthostomidae, Cryptogonimidae, Opisthorchiidae, and Heterophyidae ${ }^{12}$, which infects reptiles, mammals, and birds in Brazil ${ }^{13}$.

Chaetotaxic investigations were useful to refine the taxonomical classifications at the family level since the distribution of sensory receptors is phylogenetically based ${ }^{2}$. Thus, the pattern was consistent with that of the family Heterophyidae. This was mostly due to the absence of CI dorsal receptors and similar caudal and dorsal body patterns ${ }^{1}$.

The infection of $M$. tuberculatus has been maintained in the collecting sites. Throughout this study, infected snails were consistently collected in five of six foci, indicating that local vertebrates are been used as definitive hosts. Further investigations are currently been carried out to examine local vertebrates for heterophyids as well to evaluate the risks for human health ${ }^{5}$.

The presence of M. tuberculatus snails in Prainha Natural City Park and near Pedra Branca State Park is of particular concern. Considering that such exotic snails have a high reproductive capacity and unknown local predators ${ }^{14}$, they may colonize both parks rapidly. This could affect and even endanger native species.
Several investigators have demonstrated that $M$. tuberculatus may exclude populations of Biomphalaria snails, which are vectors of schistosomiasis in Brazil ${ }^{8,9,10}$. The present results indicate that a better assessment of the role of these thiarids as intermediate hosts of trematodes is required. This is particularly encouraged to evaluate the impact of using this species in the biological control of Biomphalaria in Brazil ${ }^{15}$.

\section{RESUMO}

Melanoides tuberculatus (Gastropoda: Thiaridae) como hospedeiro intermediário de Heterophyidae (Trematoda: Digenea) na região metropolitana do Rio de Janeiro, Brasil

No final da década de 60, caramujos da espécie Melanoides tuberculatus, originários do nordeste africano e sudeste asiático, foram introduzidos no Brasil. Os primeiros registros de espécimes infectados com cercárias foram feitos no Estado do Rio de Janeiro em 2001. O presente estudo relata a ocorrência de $M$. tuberculatus infectados com larvas de trematódeos na cidade do Rio de Janeiro. O sedimento dos criadouros foi coletado e peneirado através de malhas de 0,25 polegadas. Os caramujos foram transportados em recipientes com água dos criadouros, sendo medidos e posteriormente individualizados. Eles foram expostos à luz e temperatura artificiais para induzir a emergência cercariana. As cercárias mais ativas foram processadas pelos métodos de coloração diferencial e de impregnação por nitrato de prata. Os caramujos negativos foram subsequentemente dissecados. Aproximadamente 700 caramujos foram coletados. Seu comprimento variou de 1,2 a 3,3 cm. A taxa de prevalência foi de 15,76\% apesar de $53,76 \%$ dos caramujos estarem infectados em uma das áreas. Os caramujos estavam infectados com rédias e cercárias do tipo pleurolofocerca. A morfologia e a quetotaxia cercarianas foram compatíveis com as da família Heterophyidae principalmente devido à presença de nadadeiras medianas dorsais e ventrais e à ausência de receptores sensoriais CI dorsais.

\section{ACKNOWLEDGMENTS}

We thank Dr. Lycia de Brito-Gitirana (UFRJ), for granting access to laboratory facilities. We are also indebted to Drs. Silvana Thiengo (FIOCRUZ), for the snail identification, and Fernando Régis diMaio (SESES), for support. Renato Silva and André Bazzanella helped out with the snail collections. Dilma Pimentel and Rui Moreira kindly granted access to collecting sites in private areas. The technical support of Luciana Fávero and Luiza Coelho (SESES) was greatly appreciated. Collections at "Parque Natural Municipal da Prainha" were conducted according to conditions set forth in a collecting permit issued to T.B. by "Secretaria Municipal do Meio Ambiente." This work was supported by a Post-doctoral fellowship and a research grant of the "Conselho Nacional de Desenvolvimento Científico e Tecnológico", Brazil, (no. 150021/2003-8) awarded to T.B.

\section{REFERENCES}

1. BAYSSADE-DUFOUR, C. - L'appareil sénsoriel des cercaries et la systématique des trématodes digenétiques. Mém. Mus. Natn. Hist. Nat. (Paris) Ser. A, 113: 1-81, 1979. 


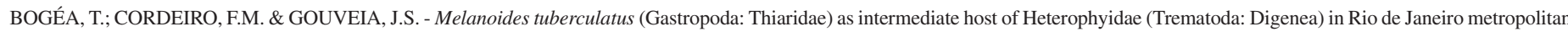
area, Brazil. Rev. Inst. Med. trop. S. Paulo, 47(2):87-90, 2005.

2. BOGÉA, T. - Functional and phylogenetic components in cercarial nervous systems. Folia Parasit. (Praha), 51: 311-319, 2004.

3. BOGÉA, T. \& CAIRA, J.N. - Ultrastructure and chaetotaxy of sensory receptors in the cercariae of a species of Crepidostomum sp. Braun, 1900 and Bunodera sp. Railliet, 1896 (Digenea: Allocreadiidae). J. Parasit., 87: 273-286, 2001.

4. CABLE, R.M. - An illustrated laboratory manual of Parasitology. Minneapolis, Burgess, 1977.

5. CHIEFFI, P.P.; LEITE, O.H.; DIAS, R.M.; TORRES, D.M.A.G.V. \& MANGINI, A.C.S. - Human parasitism by Phagicola sp. (Trematoda, Heterophyidae) in Cananéia, São Paulo State, Brazil. Rev. Inst. Med. trop. S. Paulo, 32: 285-288, 1990.

6. COMBES, C.; BAYSSADE-DUFOUR, C. \& CASSONE, J. - Sur l'impregnation et le montage des cercaires pour l'étude chétotaxique. Ann. Parasit. hum. comp., 51: $399-400,1976$

7. DEMARCO Jr., P. - Invasion by the introduced aquatic snail Melanoides tuberculata (Müller, 1774) (Gastropoda: Prosobranchia: Thiaridae) of the Rio Doce State Park, Minas Gerais, Brazil. Stud. Neotrop. Fauna Environ., 34: 186-189, 1999.

8. GIOVANELLI, A.; VIEIRA, M.V. \& COELHO DA SILVA, C.L.P.A. - Interaction between the intermediate host of Schistosomiasis in Brazil Biomphalaria glabrata (Planorbidae) and a possible competitor Melanoides tuberculata (Thiaridae). I. Laboratory experiments. Mem. Inst. Oswaldo Cruz, 97: 363-369, $2002 a$.

9. GiOVANELli, A.; COELHO DA SILVA, C.L.P.A.; MEDEIROS, L. \& VASCONCELLOS, M.C. - The molluscicidal activity of Niclosamide (Bayluscide WP70®) on Melanoides tuberculata sp. (Thiaridae), a snail associated with habitats of Biomphalaria glabrata (Planorbidae). Mem. Inst. Oswaldo Cruz, 97: 743-745, $2002 b$

10. GUIMARÃES, C.T.; SOUZA, C.P. \& SOARES, D.M. - Possible competitive displacement of planorbids by Melanoides tuberculata in Minas Gerais, Brazil. Mem. Inst. Oswaldo Cruz, 96 (suppl. 1): 173-176, 2001.
11. ROBERTS, L. \& JANOVY Jr., J. - Foundations of Parasitology. Boston, Wm. C. Brown, 1998

12. SCHELL, S.C. - Trematodes of North America [and] North Mexico. Moscow, The University of Idaho Press, 1985.

13. THATCHER, V. - Trematódeos neotropicais. Manaus, Instituto Nacional de Pesquisas da Amazônia, 1993.

14. THIENGO, S.C.- Caramujo africano. Bionotícias, 63: 8, 2003.

15. THIENGO, S.C.; FERNANDEZ, M.A. \& DE SIMONE, L.R.L. - Sobre a expansão de Melanoides tuberculatus (Müller, 1774) no Brasil. Tentacle, 10: 17, 2002.

16. THIENGO, S.C.; FERNANDEZ, M.A.; BOAVENTURA, M.F.F. et al. - Freshwater snails and schistosomiasis mansoni in the State of Rio de Janeiro, Brazil. I. Metropolitan Mesoregion. Mem. Inst. Oswaldo Cruz, 96(suppl.): 177-184, 2001.

17. TRAVASSOS, L.; TEIXEIRA DE FREITAS, J.F. \& KOHN, A. - Trematódeos do Brasil. Mem. Inst. Oswaldo Cruz, 67: 1-886, 1969

18. VAZ, J.F.; TELES, H.M.S.; CORREA, M.A. \& LEITE, S.P.S. - Ocorrência no Brasil de Thiara (Melanoides) tuberculata (of Müller, 1774) (Gastropoda, Prosobranchia), primeiro hospedeiro intermediário de Clonorchis sinensis. Rev. Saúde públ. (S. Paulo), 20: 318-322, 1986.

19. WATANABE, T.; PAZ, R.J.; DIJCK, M.P.M. \& ABÍLIO, F.J.P. - First record of Melanoides tuberculata (Müller, 1774) (Gastropoda: Prosobranchia: Thiaridae) in the state of Paraíba (Brazil) and its ecological implications. Rev. Nord. Biol., 10: 72-84, 1999.

Received: 14 October 2004

Accepted: 04 January 2005 